\title{
Cholecystokinin release and biliopancreatic secretion in response to selective perfusion of the duodenal loop with aminoacids in man
}

\author{
J F COLOMBEl, A SUTton, J A CHAYViAlle, AND R MODigliani \\ From the INSERM U 290, Hôpital Saint-Lazare, Paris, France and INSERM U 45, Hôpital Edouard-Herriot, \\ Lyon, France
}

summary The aim of this study was to measure the role of the duodenal loop in biliopancreatic secretion in man by infusing various stimuli at the ampulla of Vater and collecting duodenal contents at the ligament of Treitz, above an occluding balloon. Perfusion at $10 \mathrm{ml} / \mathrm{min}$ of a first mixture of aminoacids - phenylalanine (47.2 mmol), methionine (38.2 mmol), tryptophan (11 mmol), valine $(61.6 \mathrm{mmol})$ - increased cholecystokinin (CCK) plasma concentrations and duodenal bile salt output $(p<0.005)$ as compared with a control electrolyte solution, but did not change pancreatic enzyme secretion significantly; duodenal infusion of another aminoacid mixture - arginine (32.4 mmol), histidine (14.1 $\mathrm{mmol})$, leucine $(36 \mathrm{mmol})$, isoleucine $(21.5 \mathrm{mmol})$, lysine $(31 \mathrm{mmol})$, threonine (23 mmol) - did not change CCK plasma concentrations, bile salt or pancreatic enzyme output. The respective role of duodenal distension and endogenous CCK was investigated by perfusing the first aminoacid solution and the control solution at 2,5 , and $10 \mathrm{ml} / \mathrm{min}$. Changing the perfusion rate of control solution from 2 to $5 \mathrm{ml} / \mathrm{min}$ led to a significant increase $(p<0.01)$ in pancreatic secretion with no further increase at $10 \mathrm{ml} / \mathrm{min}$. Bile salt output was not influenced by the perfusion rate of control solution. During the perfusion of the aminoacid solution, despite a stepwise increase in CCK release, the only significant change in pancreatic secretion was an increase of lipase output $(p<0.05)$ when the infusion rate was raised from 2 to $5 \mathrm{ml} / \mathrm{min}$. Our results suggest that duodenal CCK release (1) depends on the nature of aminoacids (2) has a predominant role in the regulation of pancreatic secretion at low perfusion rate but is less effective when superimposed on a mechanical stimulus caused by duodenal distension (3) is a major stimulus for gall bladder contraction which is not influenced by duodenal distension.

Infusion of aminoacids (AA) intraduodenally stimulates pancreatic enzyme secretion and gall bladder contraction. ' : These effects are mediated by hormonal (essentially cholecystokinin (CCK) release) and neural pathways. ' It is accepted that stimulation of pancreatic enzyme production depends on the length of small intestine exposed to nutrients ${ }^{3}$ but it has also been shown in man that, when a meal was infused into the stomach, the gastroduodenal segment was sufficient to elicit the entire postprandial enzyme output, with the more distal bowel not modifying this output in any way. ${ }^{4}$

Address for correspondence: R Modigliani, Department of Gastroenterology, Hôpital Saint-Lazare, 75475 Paris Cedex 10, France.

Received for publication 8 April 1988.
The role of the duodenal loop itself in biliopancreatic secretion has never been directly assessed in man but it was reported in canine experiments that perfusing the proximal $10 \mathrm{~cm}$ of intestine with phenylalanine did not induce any pancreatic secretory response. ${ }^{3}$

The aim of this work was to evaluate the role of the duodenal loop, separated from the rest of the bowel by a balloon, in biliopancreatic secretion in man. Therefore we investigated (1) the effect of infusing into the duodenum two different mixtures of AA on CCK release and biliopancreatic secretion; (2) the respective role of duodenal distension and CCK in the control of biliopancreatic secretion by perfusing intraduodenally the AA mixture shown to release CCK and a control electrolyte solution at increasing infusion rates. 
Table 1 Composition of test solutions

\begin{tabular}{lcllll}
\hline Control & mmolll & AAl solution & mmolll & AA2 solution mmolll \\
\hline $\mathrm{NaCl}$ & 110 & Phenylalanine & $47 \cdot 2$ & Arginine & $32 \cdot 4$ \\
$\mathrm{NaHCO} 3$ & 35 & Methionine & $38 \cdot 2$ & Histidine & $14 \cdot 1$ \\
$\mathrm{KCl}$ & 5 & Tryptophan & 11 & Leucine & 36 \\
& & Valine & $61 \cdot 6$ & Isoleucine & $21 \cdot 5$ \\
& & & & Lysine & 31 \\
& & & & Threonine & 23 \\
\hline
\end{tabular}

\section{Methods}

SUBJECTS

Studies were carried out on 15 normal volunteers aged 20-28 years, with no history of gastrointestinal disease. Informed consent was obtained from all subjects and the protocol was accepted by the local ethical committee.

\section{TEST SOLUTIONS}

The solutions used to perfuse the duodenum consisted of a physiological electrolyte control solution (C) and of two aminoacid solutions (AA1 and AA2) whose composition is given in Table 1 . These solutions were chosen because it had been previously suggested that one of them (AA1) released CCK when perfused intraduodenally whereas the other
Table 2 Effect on biliopancreatic secretion of the inflation of a balloon located at the angle of Treitz during saline infusion at rates of 2 and $10 \mathrm{ml} / \mathrm{min}(\mathrm{mean}(S E))(n=6)$

\begin{tabular}{|c|c|c|c|c|}
\hline & \multicolumn{2}{|l|}{$2 \mathrm{ml} / \mathrm{min}$} & \multicolumn{2}{|l|}{$10 \mathrm{ml} / \mathrm{min}$} \\
\hline & $\begin{array}{l}\text { Balloon } \\
\text { inflated }\end{array}$ & $\begin{array}{l}\text { Balloon } \\
\text { not } \\
\text { inflated }\end{array}$ & $\begin{array}{l}\text { Balloon } \\
\text { inflated }\end{array}$ & $\begin{array}{l}\text { Balloon } \\
\text { not } \\
\text { inflated }\end{array}$ \\
\hline Lipase (KU/min) & $0.77(0.05)$ & $0.73(0 \cdot 1)$ & $2 \cdot 8(0 \cdot 5)$ & $2 \cdot 5(0 \cdot 5)$ \\
\hline $\begin{array}{c}\text { Chymotrypsin } \\
\text { (U/min) }\end{array}$ & $83(11)$ & $77(10)$ & $207(47)$ & $169(62)$ \\
\hline Bile salts $(\mu \mathrm{mol} / \mathrm{min})$ & $4(0 \cdot 5)$ & $2 \cdot 6(0 \cdot 4)$ & $6 \cdot 9(3 \cdot 7)$ & ) $1 \cdot 4(1 \cdot 1)$ \\
\hline
\end{tabular}

Values with and without the balloon inflated were not statistically different.

one (AA2) did not. ${ }^{5}$ The aminoacid solutions were made isoosmolar by addition of $\mathrm{NaCl}$. All solutions had an osmolality of $300 \mathrm{mosmol} / \mathrm{kg}$, contained $\mathrm{C}^{14}$ polyethylene glycol, molecular weight $3600\left(\mathrm{C}^{14}\right.$ PEG $3600,20 \mu \mathrm{Ci}$ ) as a non-absorbable marker and $200 \mathrm{mg}$ phenolsulphonephtalein (PSP) to check any leakage of the duodenal segment beyond the balloon into the jejunum. The solutions were warmed at $37^{\circ} \mathrm{C}$ and adjusted to ph $6 \cdot 0$ before infusion.

PERFUSION TECHNIQUE AND BLOOD SAMPLING A four lumen duodenal tube (Fig. 1) was positioned

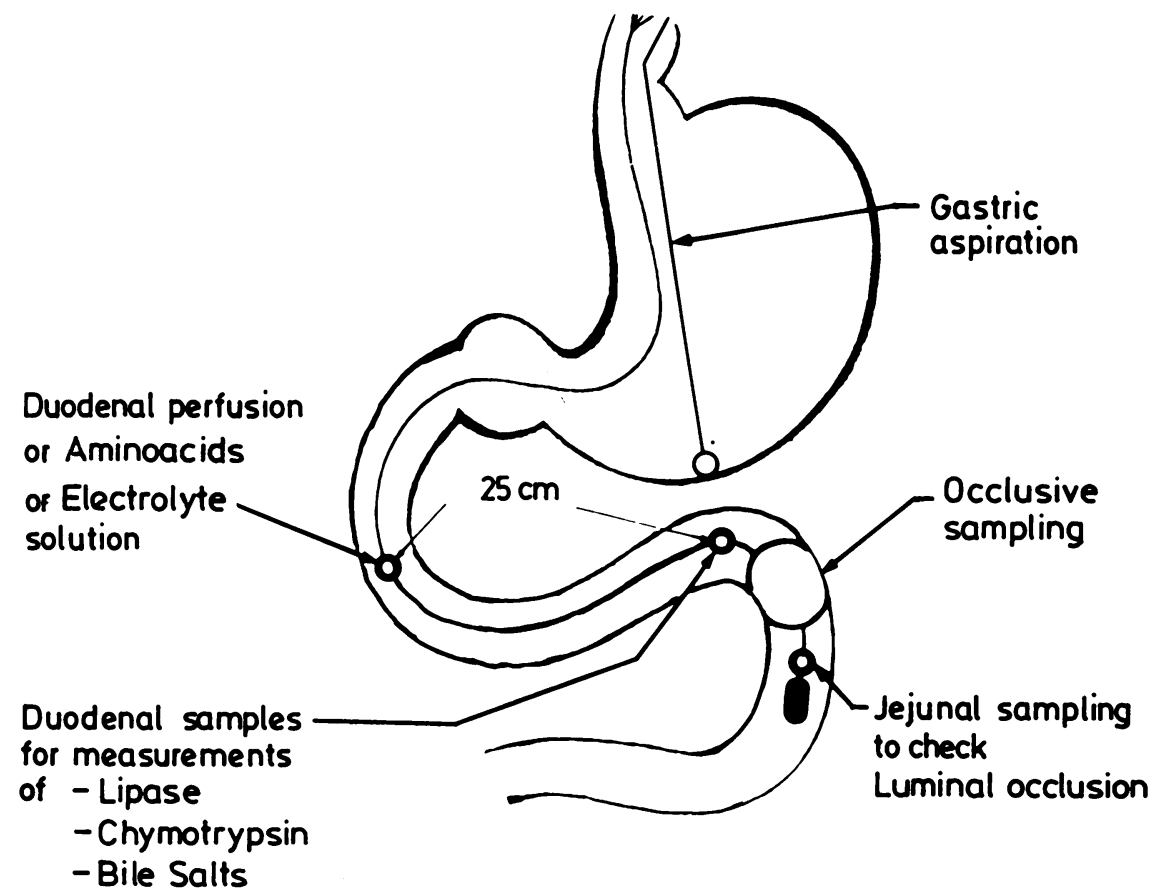

Fig. 1 Location of duodenal and gastric tubes. 
fluoroscopically with a perfusion site at the ampulla of.Vater and the collection port at the ligament of Treitz above an inflatable balloon. During all experimental periods the balloon was inflated through the third tube with $45-60 \mathrm{ml}$ air until the subject became aware of its presence; its tightness was repeatedly checked by the failure to detect PSP in the jejunal aspirate collected beyond the balloon through the fourth tube. In previous validation studies we found that inflation of this balloon at the angle of Treitz did not cause any change in biliopancreatic secretion as measured during saline infusion at rates of 2 and $10 \mathrm{ml} / \mathrm{min}$ (Table 2). The duodenal segment was continuously aspirated from its sampling point by siphonage with intermittent manual syringe aspiration to ensure continuous flow. During the last 60 minutes of each test period four 15 minutes samples were collected for analysis of the duodenal aspirate.

Venous blood was first obtained at the beginning of the experiments before intestinal perfusion, then every 30 minutes during control periods and every 15 minutes during AA periods. Blood was drawn into ice chilled glass tubes containing aprotinin and heparin. It was immediately centrifuged $(3000 \mathrm{~g} \times 10$ $\min )$ at $4^{\circ} \mathrm{C}$ and the plasma stored at $-80^{\circ} \mathrm{C}$.

\section{STUDY PROTOCOL}

\section{Preliminary study (study 1)}

The duodenal loop was perfused at $10 \mathrm{ml} / \mathrm{min}$ with solutions $\mathrm{C}, \mathrm{AA} 1$ and $\mathrm{AA} 2$ in eight subjects. Each
AA period (75 minutes) was preceded and followed by a $C$ period ( 90 minutes); the order of perfusion of the two AA solutions was randomised. Steady state conditions (as assessed by $\mathrm{C}^{14}$-PEG 3600 concentrations) were achieved after 15 minutes) in all subjects. Lipase, chymotrypsin, bile salts and $C^{14}$-PEG 3600 concentrations were measured in duodenal aspirates. For each subject values obtained during the three $\mathrm{C}$ periods were averaged.

\section{Main study (study 2)}

In this study biliopancreatic secretion in response to selective duodenal perfusion with $\mathrm{C}$ and AA1 solutions at increasing rates $(2 \mathrm{ml} / \mathrm{min}, 5 \mathrm{ml} / \mathrm{min}, 10$ $\mathrm{ml} / \mathrm{min}$ ) was assessed in seven subjects over a twoday experiment. The duodenum was perfused with $C$ solution during one day and AA1 solution during the other day in a randomised order. Each test day consisted of the following periods: $2 \mathrm{ml} / \mathrm{min}(120$ $\mathrm{min}), 5 \mathrm{ml} / \mathrm{min}(90 \mathrm{~min})$, and $10 \mathrm{ml} / \mathrm{min}(90 \mathrm{~min})$. Within each of the various experimental periods the concentrations of PEG in the successive 15 minute samples showed little variation after an equilibration period of 30-45 minutes when the perfusion rate was $2 \mathrm{ml} / \mathrm{min}, 15-30$ minutes at $5 \mathrm{ml} / \mathrm{min}$, and 15 minutes at $10 \mathrm{ml} / \mathrm{min}$. Lipase, chymotrypsin, bile salt and $\mathrm{C}^{14}$ PEG 3600 concentrations were assayed in all duodenal samples. A gastric sump tube was positioned in the antrum allowing continuous aspiration of gastric contents. The percentage of duodenal reflux into the
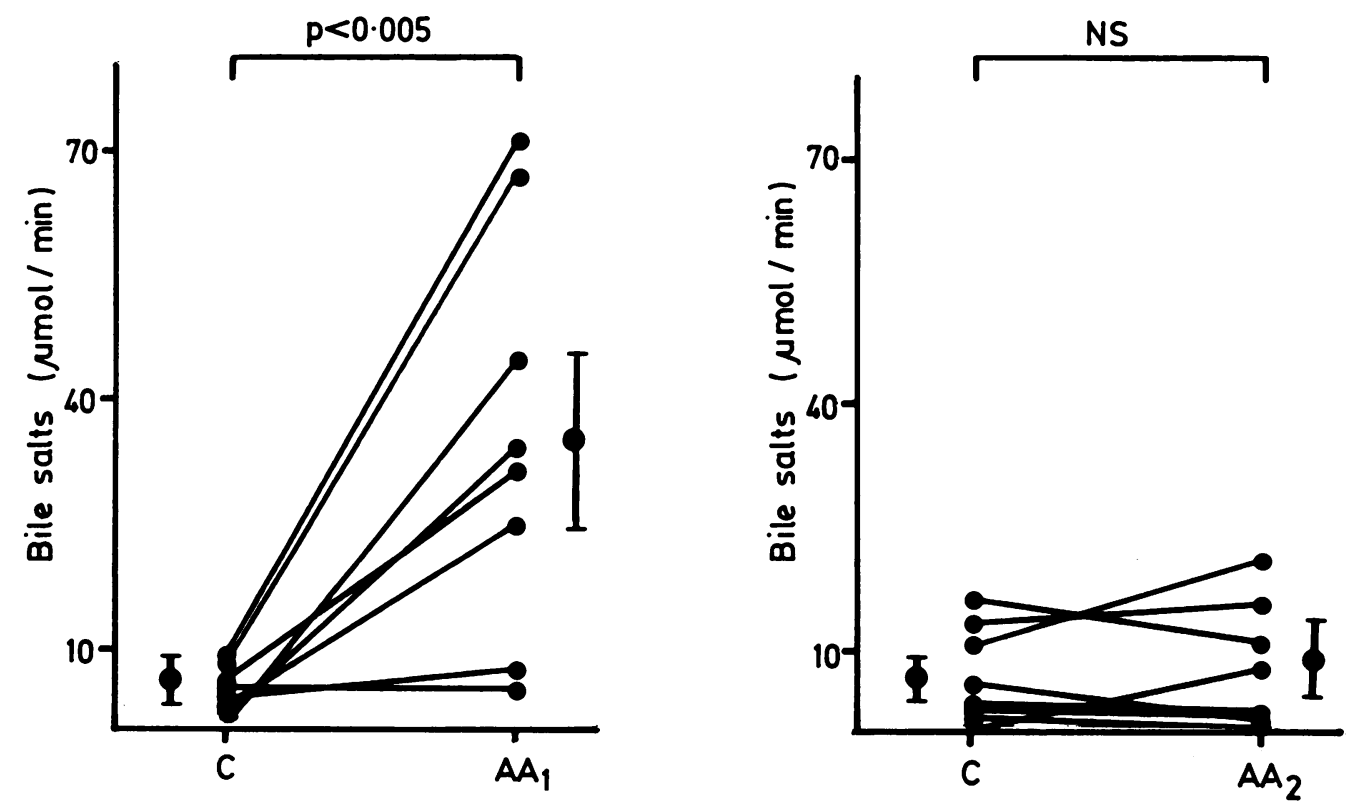

Fig. 2 Output of bile salts during the perfusion of control and aminoacid solution at $10 \mathrm{ml} / \mathrm{min}$. Individual values and mean (SE) are shown. Significant stimulation was seen with AA1 solution only $(p<0.005)$. 
stomach, as assessed by recovery of $\mathrm{C}^{14}$-PEG in gastric contents, was determined for each period.

CHEMICAL ANALYSIS AND $\mathrm{C}^{14}-\mathrm{PEG}$ COUNTING $\mathrm{C}^{1+}-\mathrm{PEG}$ was measured in duodenal and gastric samples by $b$ scintillation. Lipase, chymotrypsin and bile salts were assayed in all duodenal samples kept in ice using standard methods. ${ }^{\text {th }}$.

\section{RADIOIMMUNOASSAYS}

Cholecystokinin like immunoreactivity was measured on coded samples with antiserum $67 \mathrm{H}$, raised in a New Zealand white rabbit injected with purified porcine CCK-33 (V Mutt) conjugated to bovine albumin through ethyl carbodiimide condensation. The antiserum bound with equal potencies all C-terminal sulphated sequences of nine or more residues (CCK-33-39, CCK-10, Threonine 28Norleucine 31 CCK-nonapeptide, CCK-8), with a maximum affinity constant of $6 \cdot 24 \times 10^{\prime \prime} \mathrm{l} / \mathrm{mol}$. The cross reactivity was $30 \%$ for sulphated CCK-8, $2 \%$ for sulphated Gastrin-17, and less than $1 \%$ for non sulphated Gastrin-17 and CCK-8. The C-terminal decapeptide CCK-24-33 (gift from E Wünsch) was labelled with the Bolton and Hunter reagent according to Fourmy et al. ${ }^{4}$ Purified porcine CCK-33 was used as standard. The CCK-related components present in human plasma, in basal conditions and under intraduodenal infusion of triglycerides, "' were characterised after extraction of pooled plasma on octadecasilylsilica cartridges (Sep Pak - Waters) followed by gel filtration on G50 superfine Sephadex. Three molecular forms were detected, respectively eluted in the volume of CCK-33-39, intermediate to CCK-33 and CCK-8, and in the volume of CCK-8. The ID 50 in presence of $20 \%$ charcoal treated human plasma was about 5 fmol per tube for a maximal specific binding of $27-35 \%$. Results were expressed as pmoles per litre of plasma.

CALCULATION AND EXPRESSION OF RESULTS

Outputs of enzymes and bile salts were calculated by multiplying their concentrations in each sample by the corresponding flow rates measured at the angle of Treitz. Flow rates at the angle of Treitz were derived from $\mathrm{C}^{14}$-PEG concentrations in test solutions and duodenal aspirates using standard formulae."

For each subject values of the four samples obtained during the various experimental periods were averaged. Results are expressed as mean (SE). Control values in study 1 were obtained by averaging the results of the three $\mathrm{C}$ periods. Statistical analysis was carried out by the Student's $t$ test for paired data.

\section{Results}

No leakage of duodenal contents beyond the inflated
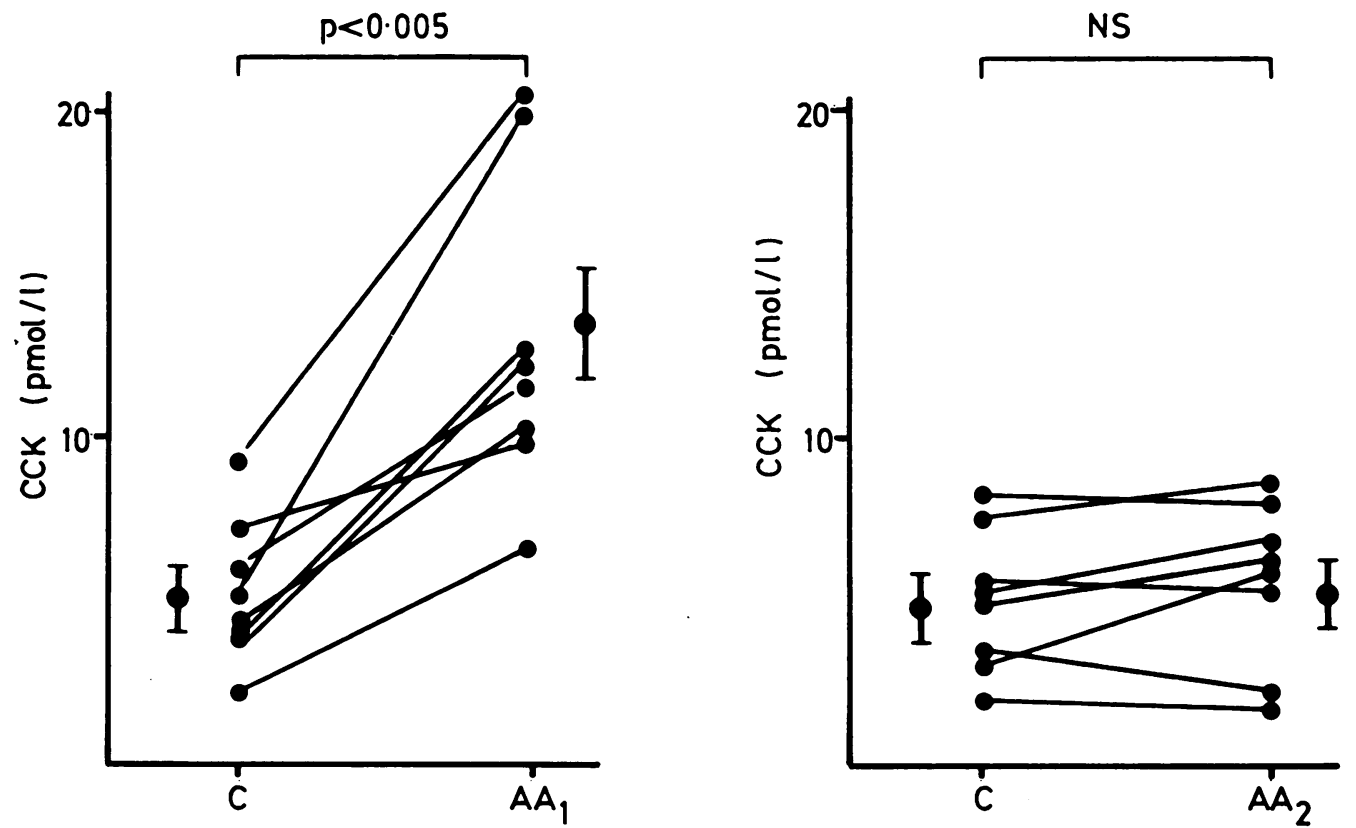

Fig. 3 CCK plasma concentrations during the perfusion of control and aminoacid solutions at $10 \mathrm{ml} / \mathrm{min}$. Individual values and mean (SE) are shown. Significant increase was seen with AAl solution only $(p<0 \cdot 005)$. 

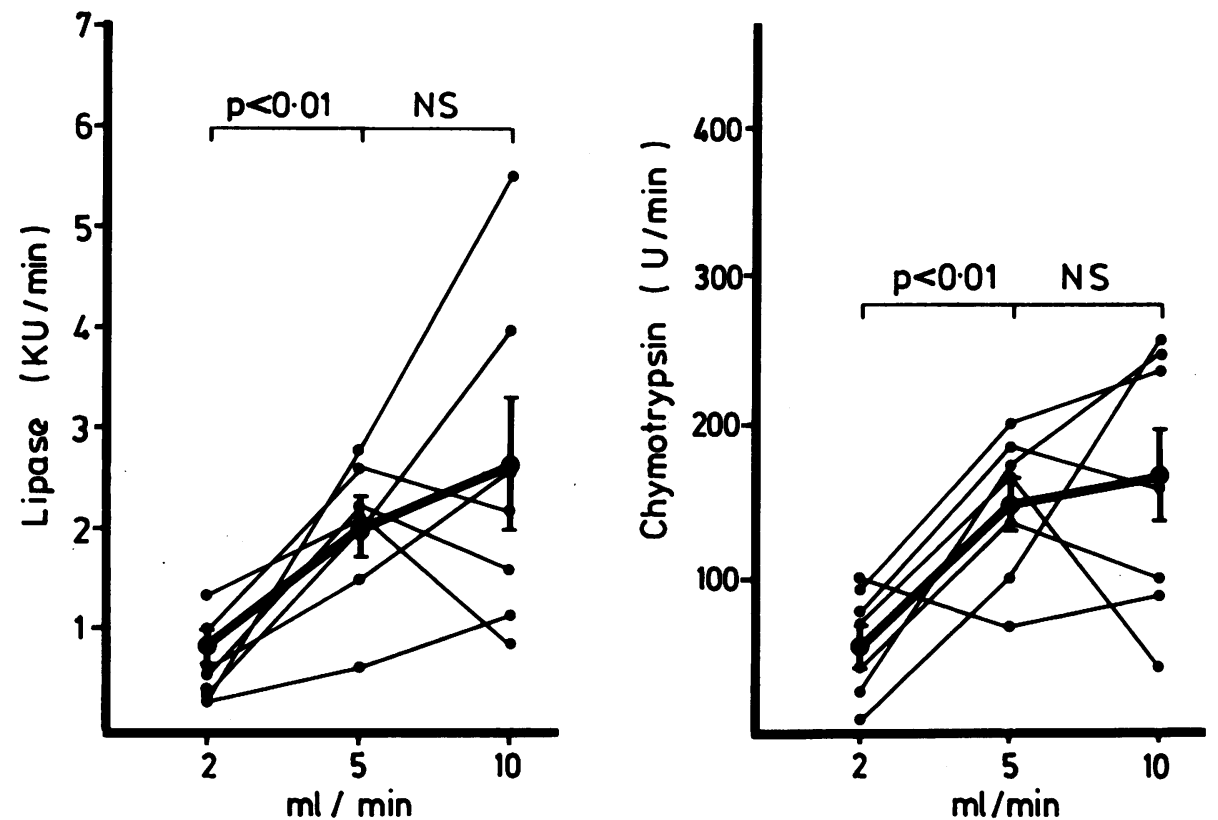

Fig. 4 Output of pancreatic enzymes during duodenal infusion of control solution at increasing perfusion rates. Individual values and mean (SE) are shown. Changing the duodenal perfusion rate from 2 to $5 \mathrm{ml} / \mathrm{min}$ led to a significant increase in lipase and chymotrypsin $(p<0 \cdot 01)$ outputs. No further significant increase was seen at $10 \mathrm{ml} / \mathrm{min}$.

balloon occurred as shown by the absence of PSP in the jejunal samples.

\section{STUDY 1}

Selective duodenal infusion $(10 \mathrm{ml} / \mathrm{min})$ of AA1 induced a frank increase in bile salt output (Fig. 2) but a small and non-significant augmentation of lipase and chymotrypsin secretion: 2.12 (0.44) $\mathrm{kU} / \mathrm{min} v 1.53(0.6)$ and 141 (35) U/min $v 119$ (18) respectively. There was concomitantly a sharp increase in plasma CCK concentrations (Fig. 3). By contrast duodenal infusion of AA2 did not change bile salt output (Fig. 2), lipase and chymotrypsin secretion $(1.32(0.6) \mathrm{kU} / \mathrm{min} v 1.53(0.6)$ and $104(20)$ U/min $v 119$ (18) respectively) or plasma CCK concentrations (Fig. 3).

STUDY 2

Effect of increasing duodenal perfusion rates on biliopancreatic secretion and plasma $C C K$

concentrations.

Control electrolyte solution: as shown on Figure 4, changing the duodenal perfusion rate from 2 to $5 \mathrm{ml} / \mathrm{min}$ led to a parallel and significant increase in lipase and chymotrypsin outputs. When the perfusion rate was switched to $10 \mathrm{ml} / \mathrm{min}$ there was a trend for a further increase in enzyme outputs but this was not statistically significant. Bile salt outputs were somewhat erratic and did not undergo significant changes on increasing duodenal perfusion rates (Table 3). Likewise there was no significant influence of duodenal perfusion rates on CCK plasma levels (Table 3). Gastric reflux occurred only at a perfusion rate of $10 \mathrm{ml} / \mathrm{min}$ and averaged $8 \pm 2 \%$.

AA1 solution: as shown on Figure 5 changing the duodenal perfusion rate from 2 to $5 \mathrm{ml} / \mathrm{min}$ caused a significant increase in lipase output but no significant change in chymotrypsin secretion. When the perfusion rate was switched to $10 \mathrm{ml} / \mathrm{min}$ there was no significant further increase in pancreatic enzyme outputs. Bile salt outputs were respectively $(\mu \mathrm{mol} /$ min) $17.9(3.5), 18.9(5.3)$, and $8.7(3.9)$ at infusion rates of 2,5 , and $10 \mathrm{ml} / \mathrm{min}$. The lower value observed at $10 \mathrm{ml} / \mathrm{min}$ was likely to be caused by the rupture of the enterohepatic cycle caused by the initial part of the protocol. Finally CCK plasma concentrations increased significantly in parallel to the infusion rates (Fig. 6). As in control periods gastric reflux occurred only at a perfusion rate of 10 $\mathrm{ml} / \mathrm{min}$ and averaged $7(3) \%$.

Comparative effects of electrolyte and $A A 1$ solution on biliopancreatic secretion and CCK plasma concentrations.

At any given infusion rate, the pancreatic enzyme outputs measured during duodenal infusion of AA1 tended to be superior to that obtained during infusion 

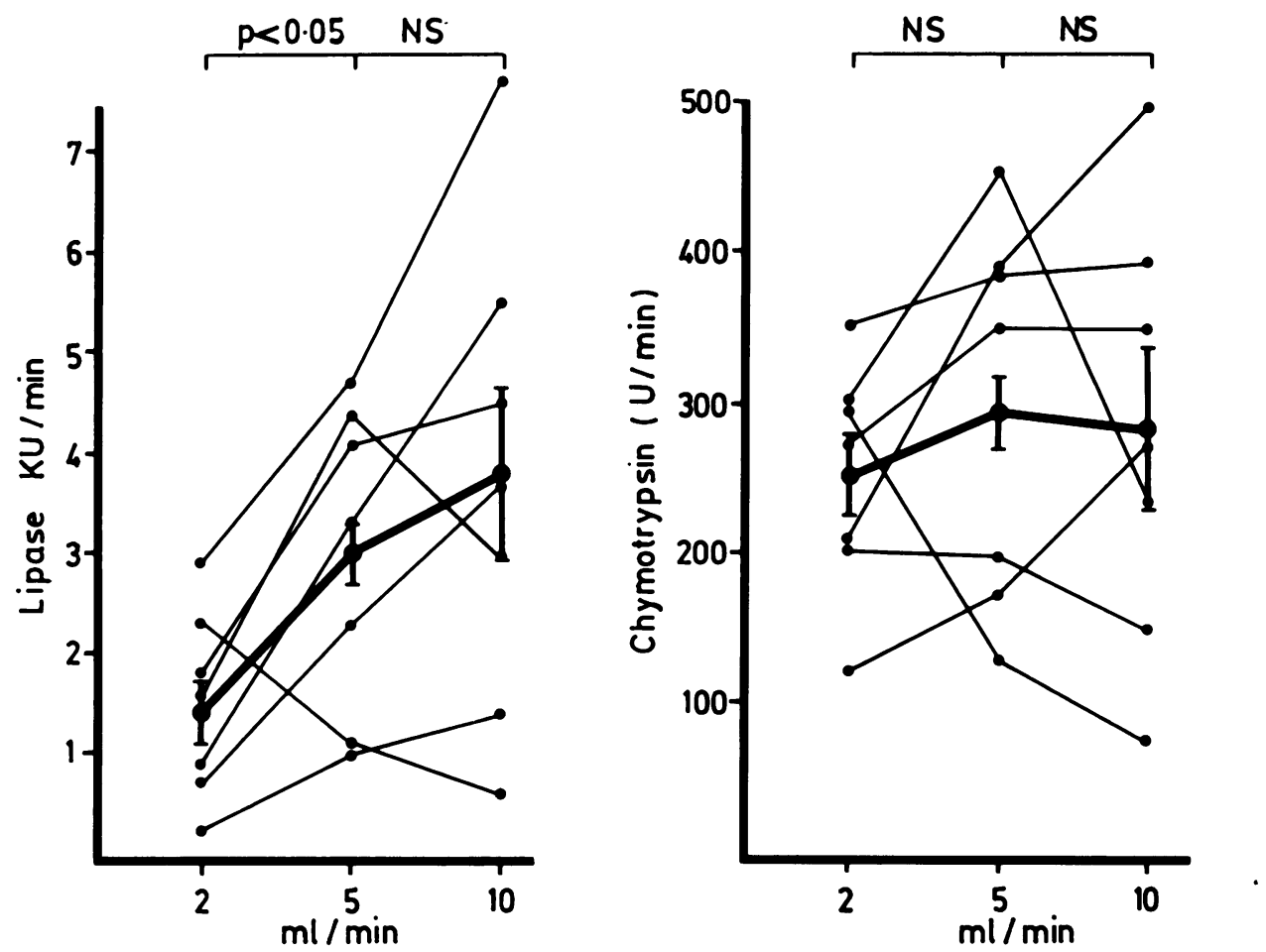

Fig. 5 Output of pancreatic enzymes during duodenal infusion of AAl solution at increasing perfusion rates. Individual values and mean (SE) are shown. Changing the duodenal perfusion rate from 2 to $5 \mathrm{ml} / \mathrm{min}$ led to a significant increase in lipase output $(p<0.05)$ but to no significant change in chymotrypsin secretion. No further significant increase was seen at $10 \mathrm{ml} / \mathrm{min}$ for both enzymes.

of $C$. For chymotrypsin this difference was significant at infusion rates of 2,5 , and $10 \mathrm{ml} / \mathrm{min}$ with a $4 \cdot 34$, 1.98 , and 1.75 fold increase respectively (Fig. 7 ). For lipase the difference between AA1 and C solution was only significant at $2 \mathrm{ml} / \mathrm{min}$ representing a $2 \cdot 38$ fold increase of secretion (Fig. 7). Bile salt outputs were much higher with AA1 (given in the previous paragraph) than with $\mathrm{C}$ solution (Table 3 ) at infusion rates of $2 \mathrm{ml} / \mathrm{min}$ ( 15 fold increase) and $5 \mathrm{ml} / \mathrm{min}(4.3$ fold increase) but the difference was smaller at $10 \mathrm{ml} /$ min merely reflecting a previous depletion of the bile salt pool. Finally plasma CCK concentrations were significantly higher during AA1 (Fig. 6) than during $C$ (Table 2) infusion at any rate; the difference increased in parallel with the infusion rate with a 1.27 $(\mathrm{p}<0.025), 2.4(\mathrm{p}<0.025)$, and $3.14(\mathrm{p}<0.0005)$ fold increase at 2,5 , and $10 \mathrm{ml} / \mathrm{min}$ respectively.

\section{Discussion}

The pancreatic response to a meal can be divided into three phases: cephalic, gastric, and intestinal and results from a complex interplay of both hormonal and neural pathways. There is much evidence to suggest that the duodenal loop itself is prevalent in the control of the intestinal phase although its specific role has never been assessed in man.

We measured biliopancreatic secretion in response to stimulation of the duodenal loop, using an occlusive balloon at the ligament of Treitz, and in the absence of significant duodenogastric reflux. Our results clearly showed that the stimulation of a $25 \mathrm{~cm}$ segment below the papilla is able to release CCK in response to chemical stimuli and to induce biliopancreatic secretion in response to mechanical or chemical stimuli. Although the jejunoileal segment possesses mechanisms able to influence pancreatic exocrine function, Miller et al showed that the control of human postprandial pancreatic secretion is a function of the gastroduodenal region. ${ }^{4}$ Because the best understood role for the stomach in regulating pancreatic secretion is as a determinant of the rate of gastric emptying of chyme into the intestine, this study suggests that the duodenal loop could play a major role within the gastroduodenal segment.

Although CCK has been recognised to play a predominant role in the intestinal phase of pancreatic secretion, recent observations emphasise the import- 


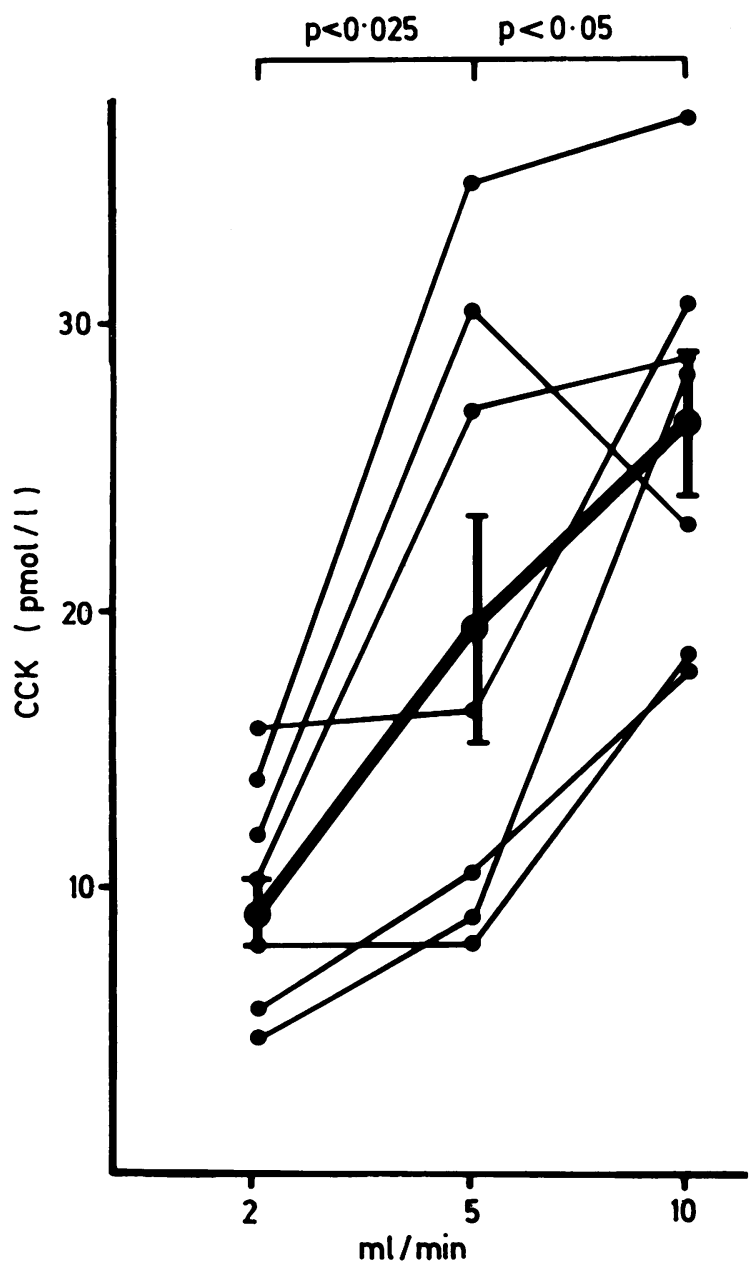

Fig. 6 CCK plasma concentrations during duodenal infusion of $A A I$ solution at increasing perfusion rates. Individual values and mean (SE) are shown. Significant increase was seen when the duodenal perfusion rate was switched from 2 to $5 \mathrm{ml} / \mathrm{min}(p<0.025)$ and from 5 to 10 $\mathrm{ml} / \mathrm{min}(p<0.05)$.

ance of neural pathways in pancreatic secretory response to food. ${ }^{12-14}$ In man, the major argument favouring a CCK independent control mechanism of pancreatic enzyme secretion has been the stimulation of enzyme production in response to increasing duodenal perfusion rate of saline solution ${ }^{15} 16$ and to instillation of hyperosmotic solution. ${ }^{16}$ This suggests the existence of volume and osmoreceptors mediating pancreatic exocrine secretion somewhere in the small intestine as in these experiments the duodenal loop was not isolated and the saline solution not interrupted at the angle of Treitz. In our work while a balloon was inflated at the angle of Treitz, we also
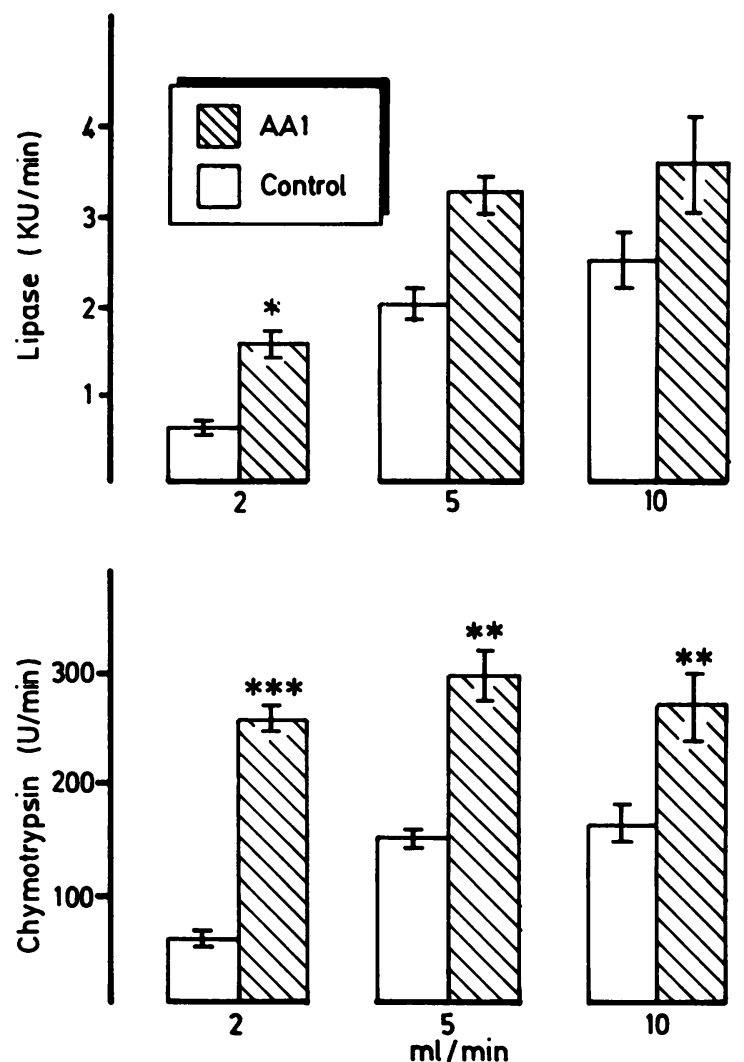

Fig. 7 Comparative effects of control and AAl solution on lipase and chymotrypsin outputs at different perfusion rates.

$*=$ significantly higher than control values $p<0.05$,

$* *=$ significantly higher than control values $p<0.0025$,

$* * *=$ significantly higher than control values $p<0.0005$.

observed a frank increase of pancreatic enzyme output on switching the infusion rate of the saline solution from 2 to $5 \mathrm{ml} / \mathrm{min}$. As the order of magnitude of this change was similar to those observed when the whole intestine was perfused, ${ }^{15} 16$ it is likely that volume receptors are mainly located in the duodenum. A further increase of the perfusion rate (from 5 to $10 \mathrm{ml} / \mathrm{min}$ ) induced a minor and non significant increment of enzyme production suggest-

Table 3 Effect of duodenal infusion of control solution at increasing perfusion rates on bile salt output and CCK plasma levels (mean (SE))

\begin{tabular}{llll}
\hline & $2 \mathrm{ml} / \mathrm{min}$ & $5 \mathrm{ml} / \mathrm{min}$ & $10 \mathrm{ml} / \mathrm{min}$ \\
\hline Bile salts $(\mu \mathrm{mol} / \mathrm{min})$ & $1.2(0.6)$ & $4.4(1.8)$ & $3.9(2.2)$ \\
CCK $(\mathrm{pmol} / \mathrm{l})$ & $7.3(0.9)$ & $8.1(1.1)$ & $8.5(1.6)$
\end{tabular}

Differences between the values for different perfusion rates were not statistically significant. 
ing that volume receptors are saturable. It should be noticed that $10 \mathrm{ml} / \mathrm{min}$ is superior to the duodenal output observed in the postprandial phase. The volume dependent control of pancreatic secretion is probably mediated by neural cholinergic pathways because (1) we observed no change in CCK concentrations when the perfusion rate of the saline solution was increased and (2) in other studies atropine markedly suppressed the pancreatic response to intestinal tract distension..$^{15} 16$

Increasing the infusion rate of AA1 solution caused a stepwise increase of CCK release but affected much less enzyme outputs, the only significant change being an increase of lipase output when the infusion rate was raised from 2 to $5 \mathrm{ml} / \mathrm{min}$. Although pancreatic secretion and changes in plasma CCK concentrations have been correlated in man after intravenous administration of CCK, the data concerning the endogenous release of CCK are scarce. A few studies demonstrated a significant correlation between CCK release and pancreatic secretion but at variance with our protocol the nutrients were infused in the jejunum. ${ }^{17-19}$

Our results give further insights into the interplay between the mechanical and chemical stimuli of pancreatic enzyme response: at low perfusion rates $(2$ $\mathrm{ml} / \mathrm{min}$ ) the superimposition of the chemical (AA) to the mechanical (distension) stimulus strongly stimulated the secretion of both pancreatic enzymes and bile salts. At higher infusion rates $(5$ and $10 \mathrm{ml} / \mathrm{min})$ the effect of replacement of the electrolytes by the AA1 solution on enzyme secretion was blurred despite a steady increment of CCK plasma concentrations. At the rate of $2 \mathrm{ml} / \mathrm{min}$ the response to saline infusion represented respectively 42 and $23 \%$ of the secretion of lipase and chymotrypsin triggered by AA1 infusion. The corresponding figures were of $69 \%$ and $51 \%$ at $5 \mathrm{ml} / \mathrm{min}$ and of $68 \%$ and $57 \%$ at 10 $\mathrm{ml} / \mathrm{min}$. This suggests that CCK is less effective to stimulate enzyme production when superimposed on a mechanical stimulus.

The AA1 solution strongly stimulated bile salt duodenal output in both the preliminary study (infusion rate: $10 \mathrm{ml} / \mathrm{min}$ ) and the main study, at infusion rates of 2 and $5 \mathrm{ml} / \mathrm{min}$. In the latter study, bile salt output diminished during the last experimental period (infusion of AA1 solution at 10 $\mathrm{ml} / \mathrm{min}$ ). This may have been due to the interruption of the enterohepatic cycle caused by total aspiration of duodenal contents at the angle of Treitz during the preceding 210 minutes. The aminoacid induced gall bladder contraction was most probably mediated by CCK. Interestingly enough, increasing perfusion rates of the saline solution did not influence bile salt output, suggesting that gall bladder contraction is not triggered by duodenal volume receptors, although other neural pathways might be involved in gall bladder stimulation. ${ }^{20}$

Finally we confirmed that CCK release by the duodenum was dependent upon the nature of the AA infused $^{21}$ : in contrast to AA1 mixture the AA2 solution did not change at all CCK concentrations and bile salt secretion. The nature of the mucosal 'receptor' triggering duodenal CCK release remains unknown. Any future hypothesis about its physiology should account for its apparent dependence upon the nature of the AA.

The authors thank Mrs M Rongier, M Maurel, M Bovet, C Franchisseur, and C Bernard for technical assistance and $\mathrm{C}$ Debuchy for typing the manuscript.

\section{References}

1 Solomon TE. Regulation of pancreatic secretion. Clin Gastroenterol 1984; 13: 657-78.

2 Singer MV. Réponse sécrétoire pancréatique aux stimulants intestinaux. Gastroentérol Clin Biol 1986; 10: 504-12.

3 Meyer JH, Kelly GA, Spingola LJ, Jones RS. Canine gut receptors mediating pancreatic responses to luminal L-amino acids. Am J Physiol 1976; 231: 669-77.

4 Miller LJ, Clain JE, Malagelada JR, Go VLW. Control of human postprandial pancreatic exocrine secretion. A function of the gastroduodenal region. Dig Dis Sci 1979; 24: $150-4$.

5 Thomas FB, Sinar D, Mazzaferri EL, et al. Selective release of gastric inhibitory polypeptide by intraduodenal amino acid perfusion in man. Gastroenterology 1978; 74: 1261-5.

6 Marchis-Mouren G, Sarda L, Desnuelle P. Purification of hog pancreatic lipase. Arch Biochem Biophys 1959; 82: 309-19.

7 Figarella C, Taulier J, Sarles H. Dosage de la chymotrypsine et de la trypsine dans le suc duodenal. Bull Soc Chim Biol 1965; 47: 679-86.

8 Murphy GM, Billing BH, Baron DN. A fluorimetric and enzymatic method for the evaluation of serum total bile acids. J Clin Pathol 1970; 23: 594-8.

9 Fourmy D, Pradayrol L, Antoniotti H, Esteve JP, Ribet A. Purification of radio-iodinated cholecystokinin peptides by reverse phase HPLC. J Liq Chromat 1982; 5: 757-66.

10 Guedon C, Ducrotte P, Chayvialle JA, Lerebours E, Denis $\mathrm{P}$, Colin R. Effects of intravenous and intraduodenal fat on jejunal motility and on plasma cholecystokinin in man. Dig Dis Sci 1988; 33: 558-64.

11 Modigliani R, Bernier JJ. Effects of glucose on net and unidirectional movements of water and electrolytes in the human small intestine. Biol Gastroenterol 1973; 5: 165-74.

12 Singer MV, Solomon TE, Grossman MI. Effect of atropine on secretion from the intact and transplanted pancreas in dog. Am J Physiol 1980; 238: G18-22.

13 Solomon TE, Grossman MI. Effect of atropine and vagotomy on response of transplanted pancreas. $A m \mathrm{~J}$ Physiol 1979; 236: E186-90. 
14 Singer MV, Solomon TE, Wood J, Grossman MI. Latency of pancreatic enzyme response to intraduodenal stimulants. Am J Physiol 1980; 238: G23-9.

15 Dooley CP, Valenzuela JE. Duodenal volume and osmoreceptors in the stimulation of human pancreatic secretion. Gastroenterology 1984; 86: 23-7.

16 Owyang C, May D, Louie DS. Trypsin suppression of pancreatic enzyme secretion. Differential effect on cholecystokinin release and the enteropancreatic reflex. Gastroenterology 1986; 91: 637-43.

17 Watanabe S, Shiratori K, Takeuchi T, Chey WY, You $\mathrm{CH}$, Chang TM. Release of cholecystokinin and exocrine pancreatic secretion in response to an elemental diet in human subjects. Dig Dis Sci 1986; 31: 919-24.
18 Brugge WR. Burke CA, Izzo RS, Praissman M. Role of cholecystokinin in intestinal phase of human pancreatic secretion. Dig Dis Sci 1987; 32: 155-63.

19 Izzo RS, Brugge WR, Praissman M. Immunoreactive cholecystokinin in human and rat plasma: correlation of pancreatic secretion in response to CCK. Regul Peptides 1984; 9: 21-34.

20 Fisher RS, Rock E, Malmud LS. Cholinergic effects on gallbladder emptying in humans. Gastroenterology 1985; 89: 716-22.

21 Go VLW, Hofmann AF, Summerskil WHJ. Pancreozymin bioassay in man based on pancreatic enzyme secretion: potency of specific amino acids and other digestive products. J Clin Invest 1970; 49: 1558-64. 